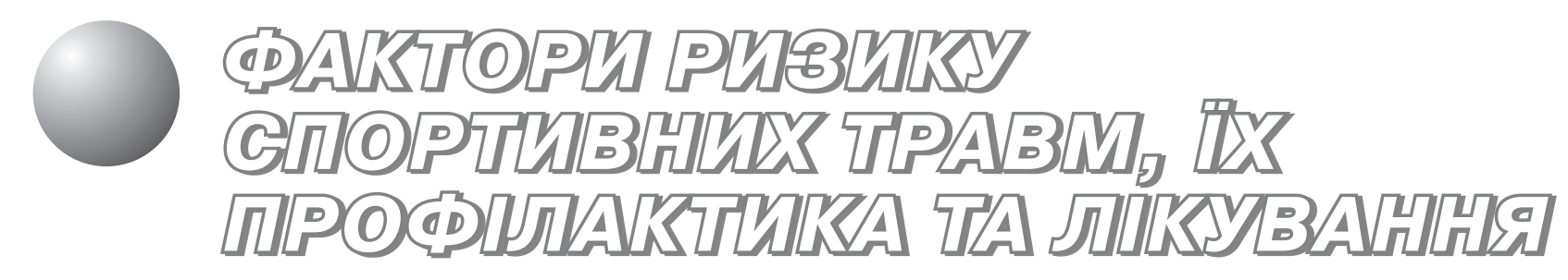

\title{
Ефективність упровадження програми профілактики і корекції порушень системи опорно-рухового апарату учнів у загальноосвітніх навчальних закладах
}

\section{С. В. Гозак, О. Ф. Воробйов}

ДУ «Інститут гігієни та медичної екології ім. О. М. Марзєєва НАМН України», Київ, Україна

Правобережний відокремлений підрозділ дУ «ЗОлЦДСЕСУ», Запоріжжя, Україна

\begin{abstract}
Резюме: Для определения эффективности внедрения программы профилактики и коррекции нарушений опорно-двигательного аппарата учащихся “Красивая осанка ребенка» в общеобразовательных учебных учреждениях изучена распространенность нарушений опорно-двигательного аппарата среди 178332 школьников г. Запорожье за период 20102012 гг. Установлено, что за два года внедрения программы риск развития нарушений опорно-двигательного аппарата среди детей школьного возраста уменьшился на 16, 1 \%, нарушений осанки - на 18,0, плоскостопия - на 19,0\% $(p<0,001)$.

Ключевые слова: учащиеся общеобразовательных учебных учреждений, опорнодвигательный апарат, нарушения осанки, плоскостопие, относительный риск.
\end{abstract}

Summary: Objective. To determine the efficiency of the introduction of the programme on the prophylaxis and correction of locomotor system disorders of the schoolchildren at secondary educational institutions. We have studied of dissemination of the disorders of locomotor system among 178332 schoolchildren of the city of Zaporozhia for the period of 2010-2012. We have determined that a risk of the development of locomotor system disorders among the children of school age was decreased by $16,1 \%$, posture disorders - by $18,0 \%$, platypodia - by $19,0 \%(p<0,001)$.

Key words: schoolchildren of secondary educational institutions, locomotor system, posture disorders, platypodia, relative risk.

Постановка проблеми. Стиль життя сучасних школярів характеризується високим рівнем статичного, сенсорного та інформаційного навантаження і низьким рівнем загальної рухової активності, що $\epsilon$ фракторами ризику розвитку порушень опорно-рухового апарату (ОРA) [4]. Функціональні розлади та початкові стадії захворювань ОРА, які виникають в період інтенсивного росту та розвитку організму, при несвоєчасному виявленні та лікуванні переходять у хронічні форми, спричиняють вертеброгенні захворювання та негативно впливають на якість подальшого життя.

Збільшення набутих порушень постави і плоскостопості у сучасних школярів визначається зростанням випадків незначної (і тому - незареєстрованої) травматизації структур хребетнорухового сегмента (XPC) хребта і в цілому ОРА через їх системну слабкість, що $€$ результатом дії комплексу фракторів: незбалансованого харчування 3 недостатністю структурних елементів кісткового і хрящового синтезу, низького рівня загальної рухової активності, відсутності в повсякденному житті та навчальному процесі фрізичних навантажень для тренування корсетних м'язів хребта тощо [6].

Виходячи зі значної поширеності порушень OPA у школярів, а також збільшення таких шкільних фракторів ризику в сучасному освітньому 
процесі, як високий рівень статичного навантаження в положенні сидячи, вимушена поза під час навчання, зниження рівня рухової активності дітей, нераціональне харчування, нами розроблено і впроваджено програму «Красива постава дитини». Вона базується на ранній діагностиці порушень ОРА, системі диференційованих заходів профілактики і корекції порушень ОРА для здорових дітей та учнів з набутими порушеннями постави, $з$ урахуванням морфоорункціональних особливостей дітей в процесі росту і розвитку [2]. Спочатку програму «Красива постава» було впроваджено у загальноосвітньому навчальному закладі «Основа» м. Запоріжжя, де протягом двох років визначили ії ефективність (частка дітей із порушеннями постави знизилась у 4,1 раза $(p<0,001)$, плоскостопістю - у 1,8 раза $(p<0,01))$, після чого методичні рекомендації було узгоджено МОЗ України та отримали висновок «Схвалено для використання у загальноосвітніх навчальних закладах» Інституту інноваційних технологій і змісту освіти МОН України.

Мета досліджень - оцінити ефективність упровадження програми «Красива постава дитини» шляхом визначення динаміки поширеності OPA у школярів загальноосвітніх навчальних закладів на рівні району та міста (на прикладі Запоріжжя).

Методи, організація досліджень. Проаналізовано особливості постави та захворюваності у 178332 дітей молодшого, середнього та старшого шкільного віку шкіл Запоріжжя за період 2010-2012 рр. У 2010 році проводили визначення початкового рівня показників, у 2011-му визначили результати першого року, а у 2012-му - другого року впровадження програми. Особливості захворюваності школярів Запоріжжя вивчали шляхом копіювання даних з медичної документації (облікової форми «Медична карта дитини» Ф.026/O). Програма включала тренінги у кожному районному управлінні освіти для адміністрації та методистів загальноосвітніх навчальних закладів щодо навчання особливостей програми.

У загальній групі дослідження окремо виділили групу дітей Орджонікідзевського району м. Запоріжжя (25 716 учнів), оскільки в цьому районі був застосований інший алгоритм впровадження програми (з додатковими заходами): батьківські збори в кожній школі району за участі лікаря-гігієніста для ознайомлення з програмою та лекцією щодо здоров'я ОРА; навчання педагогів проведенню спеціальних фрізичних вправ; у $60 \%$ загальноосвітніх навчальних закладів району стан ОРА дітей визначали за результатами оглядів дітей лікарем-ортопедом (окрім копіювання даних із медичної документації). Лікувальні та коригувальні заходи для дітей із виявленими порушеннями ОРА були призначені лікарем-ортопедом.

Вивчення особливостей динаміки показників захворюваності проводили шляхом побудови лінійної регресійної моделі. Для узагальненої оцінки тенденцій динамічного ряду використовували показник середнього темпу (Т) приросту (зниження), який виражали у відсотках і розрахували за фоормулою [1]: $T=(b / a) \cdot 100$, де $a-$ середньоарифметичний показник рівня ряду; $b-$ кутовий коефіцієнт регресії.

Для підтвердження доказовості отриманих результатів використовували методику розрахунку відносного ризику (RR) та довірчого інтервалу (ДІ) $[1,5]$.

Систематизація матеріалу і математична обробка виконані за допомогою Microsoft EXCEL 2013.

Результати досліджень та їх обговорення. Абсолютні дані щодо результатів вивчення стану опорно-рухового апарату школярів м. Запоріжжя та Орджонікідзевського району цього міста представлені у таблиці 1.

Отже, у м. Запоріжжя у 2010 р. поширеність хвороб ОРА становила 231,4, у Орджонікідзевському районі - 245,7 \% (рис. 1). У результаті першого року впровадження програми «Красива постава» даний показник знизився у місті до 206,8 , у районі - до 222,2 \%. Дослідження, проведені наприкінці другого року впровадження програми, тобто у кінці 2012-го року, показали чітке подальше зниження поширеності хвороб ОРА у місті до 194,3 , у районі до 191,2 \%. Порівняння показників 2011- та 2012-го років свідчать про більш виражене зниження рівня поширеності хвороб ОРА

ТАБЛИЦЯ 1 - Кількість школярів, які брали участь у реалізації профілактичної програми «Красива постава»

\begin{tabular}{|c|l|c|c|}
\hline \multirow{2}{*}{ Рік } & \multicolumn{1}{|c|}{ Кількість дітей } & Запоріжжя & $\begin{array}{c}\text { Орджонікі- } \\
\text { дзевський } \\
\text { район }\end{array}$ \\
\hline \multirow{4}{*}{2010} & Усього & 58838 & 8371 \\
\cline { 2 - 4 } & Із порушеннями ОРА всього & 13616 & 2057 \\
\cline { 2 - 4 } & Із порушеннями постави & 3008 & 583 \\
\cline { 2 - 4 } & Із плоскостопістю & 7549 & 1178 \\
\hline \multirow{4}{*}{2011} & Усього & 59946 & 8704 \\
\cline { 2 - 4 } & Із порушеннями ОРА всього & 12397 & 1934 \\
\cline { 2 - 4 } & Із порушеннями постави & 2719 & 601 \\
\cline { 2 - 4 } & Із плоскостопістю & 6670 & 866 \\
\hline \multirow{4}{*}{2012} & Усього & 59548 & 8641 \\
\cline { 2 - 4 } & Із порушеннями ОРА всього & 11568 & 1652 \\
\cline { 2 - 4 } & Із порушеннями постави & 2490 & 444 \\
\cline { 2 - 4 } & Із плоскостопістю & 6214 & 797 \\
\hline
\end{tabular}


у Орджонікідзевському районі (на 14,0%), ніж у цілому у місті (на 6,1 \%).

Для аналізу динаміки поширеності хвороб ОРА і подальшого прогнозу було побудовано лінійні моделі для м. Запоріжжя: $y=-18,6 x+$ $+210,8$; для Орджонікідзевського району: $y=$ $=-27,3 x+219,8$.

Оцінка тенденцій динамічних рядів за допомогою розрахунку показників лінійної залежності при вирівнюванні ряду методом найменших квадратів дозволила визначити, що у місті середній темп зниження поширеності захворювань ОРА становить 8,8 , у районі - $12,4 \%$. Таким чином, прогнозовані показники поширеності ОРА внаслідок впровадження програми «Красива постава» серед школярів м. Запоріжжя становитиме у 2013-му році - 177,2, у 2014-му - 161,6, у 2015 -му - 147,4. Аналогічні значення для району: 167,5, 146,7, 128,5 (див. рис.1).

Розрахунок відносного ризику показав, що у 2012-му році порівняно з 2010-м імовірність розвитку OPA у дітей м. Запоріжжя зменшилась на $16,1 \%(R R=0,84 ;$ ДI 0,82-0,86) $(p<0,001)$, у Орджонікідзевському районі - на 22,2 \% $(R R=0,78 ;$ ДI 0,73-0,82) $(p<0,001)$.

Динаміці окремих показників: порушення постави та плоскостопості - також властива лінійна залежність, що супроводжується значущим зниженням кривої ( $<<0,001)$. Для міста поширеність порушень постави характеризується моделлю $y=-4,7 x+46,1\left(R^{2}=0,78\right)$, поширеність плоскостопості $-y=-12,0 x+114,6\left(R^{2}=0,94\right)$. Для району відповідні моделі мають вигляд: $y=-9,1 x+$ $+63,4\left(R^{2}=0,98\right)$ та $y=-24,2 x+110,8\left(R^{2}=0,86\right)$.

Так, у місті поширеність порушення постави у 2010-му році становила 51,1 на 1000 школярів, у 2011 -му $-45,4 \%$, у 2012-му - 41,8 \%. Показники району становили відповідно 69,6; 69,0 і 51,4\%. Середній темп зниження поширеності порушень постави в середньому по місту дорівнює $10,1 \%$, по Орджонікідзевському району - 14,4 \%.

Поширеність плоскостопості серед дітей шкільного віку м. Запоріжжя у 2010-му році становила 128,3 , у 2011-му - 111,3, а у 2012-му $104,4 \%$. Аналогічний показник у школярів Орджонікідзевського району у 2010-му був вищим, ніж у середньому по місту і становив 140,7 \%. У 2011-му та 2012-му роках спостерігається значуще зниження показника до значень 99,5 та 92,2 \%. Середній темп зниження поширеності плоскостопості в середньому по місту становить $10,4 \%$, по району - 21,9\%.

Розрахунок відносного ризику показав, що у кінці другого року впровадження програми, порівняно з вихідним рівнем, імовірність розвитку

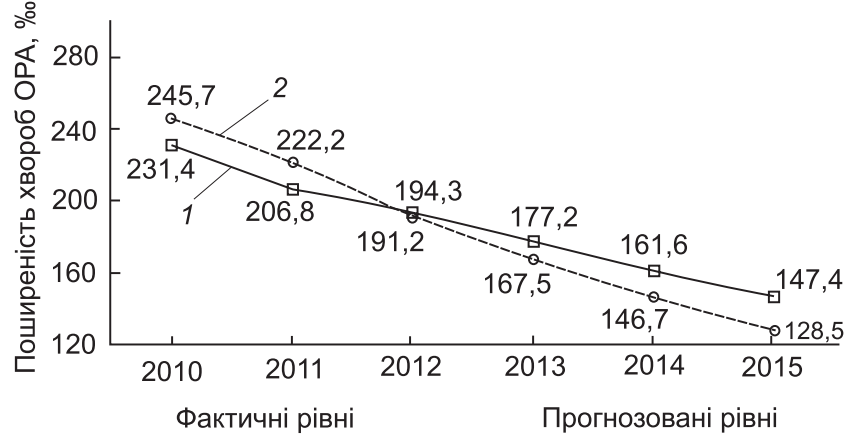

Рисунок 1 - Поширеність хвороб опорно-рухового апарату у дітей Запоріжжя (1) та Орджонікідзевського району (2) у 2010-2012 рр.

порушень постави у школярів м. Запоріжжя зменшилась на 18,0 \% (RR =0,82; ДІ 0,78-0,86) ( $<<0,001)$, у Орджонікідзевському районі - на $26,0 \%(R R=0,74 ;$ ДІ 0,65-0,83) ( $<<0,001)$.

Ймовірність розвитку плоскостопості у дітей м. Запоріжжя зменшилась на $19,0 \%(\mathrm{RR}=0,81$; ДІ 0,79-0,84) ( $<<0,001)$, у Орджонікідзевському районі - на $34,0 \%(R R=0,66$; ДІ 0,60-0,71) $(p<0,001)$.

\section{Висновки}

1. Встановлено есрективність програми профрілактики і корекції порушень опорно-рухового апарату учнів «Красива постава дитини» на рівнях міста та району міста (на прикладі м. Запоріжжя та Орджонікідзевського району міста). За період двох років упровадження програми у місті визначено середній темп зниження поширеності порушень опорно-рухового апарату у школярів $-8,8$, у районі - $12,4 \%$; поширеності порушень постави - відповідно 10,1 та 14,4 \%; поширеності плоскостопості - 10,4 та 21,9\% ( $<<0,001)$.

2. Встановлено зниження ризику розвитку порушень опорно-рухового апарату серед дітей шкільного віку у кінці 2012=го року порівняно 3 2010-м на рівні міста на 16,1\% ( $<<0,001)$, на рівні району - на 22,2 \% ( $<<0,001)$; порушень постави відповідно - на 18,0 \% ( $<<0,001)$ та $26,0 \%$ (р < 0,001); плоскостопості - на $19,0 \%$ $(p<0,001)$ та $34,0 \%(p<0,001)$.

3. 3 метою збереження і зміцнення здоров'я опорно-рухового апарату дітей необхідним $\epsilon$ широке впровадження спеціальних програм профрілактики та корекції порушень ОРА, що для підвищення їх ефективності потребує удосконалення міжвідомчої інтеграції лікарів, педагогів, спеціалістів ЛФК, а також поліпшення системи ортопедичної допомоги дітям шкільного віку на державному рівні.

\section{Рекомендації}

3 метою підвищення ефективності програми профрілактики порушень ОРА «Красива постава 
дитини» важливим $€$ дотримання певного алгоритму дій за участі медичного і педагогічного персоналу навчальних закладів, батьків, лікарів-ортопедів лікувально-профрілактичних установ за такими етапами:

1. Підготовка та поширення інорормаційних матеріалів, проведення тренінгів, лекцій, батьківських зборів. Для освоювання педагогами комплексу спеціальних вправ для розвантаження хребта і зміцнення м'язово-зв'язкового апарату дітей - проведення тренінгу для окремих груп працівників: вчителів фізичної культури, початкової школи, основної і середньої школи. Тренінги можуть проводити інструктори ЛФК, реабілітологи, лікарі зі спортивної медицини, лікарі-ортопеди, лікарі з гігієни дітей і підлітків.

Для просвіти батьків щодо коригування харчування дітей, організації робочого місця дитини, фрізкультурних пауз під час виконання домашніх завдань, необхідного рівня рухової активності тематичні батьківські збори з розповсюдженням спеціально розроблених інформаційних матеріалів та пам'яток.

2. Максимально рання діагностика порушень OPA у дітей. На першому етапі батьками та педагогами відповідно до спеціально розробленої пам'ятки «Оцінка постави школярів» формується група дітей з підозрою на порушення постави; на другому - проводиться медичний огляд дітей цієї групи лікарем-ортопедом на базі лікувальнопрофрілактичної установи або школи.

3. Для дітей без патології ОРА - активне впровадження профрілактичних заходів: корекція харчування та рухового режиму, коригування

\section{Література}

1. АнтомоноВ М. Ю. Математическая обработка и анализ медико-биологических данных / М. Ю. Антомонов. К.: Укр. военно-мед. акад., 2006. - 558 с.

2. Впровадження програми профрілактики і корекції порушень опорно-рухового апарату «Красива постава дитини» в навчальний процес закладів дошкільної та середньої освіти: метод. рек. (№ 168.11/38.12) / [Н. С. Полька, С. В. Гозак, О.Т. Єлізарова та ін.]. - К., 2012. $36 \mathrm{c}$.

3. Кучеренко В. Применение методов статистического анализа для изучения общественного здоровья и здравоохранения / В. Кучеренко, О. Манерова, Г. Краева. - М.: «ГЭОТАР-Медиа», 2007. - 192 с.

4. Кучма В. Р. Школа здоровья: организация работы, мониторинг развития и эффеективности (аудит школы в сфере здоровьесбережения детей) / [В. Р. Кучма, Л. М. Сухарева, И. К. Рапопорт и др.] - М.: Просвещение, 2011. - 142 с.

5. Ласт Д. Эпидемиологический словарь / под ред. Джона М. Ласта. - М.: Глобус, 2009. - 316 с.

6. Полька Н. С. Удосконалення медико-профрілактичного забезпечення дітей у загальноосвітніх навчальних закладах - вимога часу / Н. С. Полька, С. В. Гозак, Т. В. Станкевич // Довкілля та здоров'я. -2009. - № 1. C. 52-54. організації уроків фрізичної культури, цілеспрямовані додаткові засоби фрізичного виховання (спеціальна гімнастика під час фрізкультурних хвилинок, перерв, занять у групах продовженого дня, спортивних секціях та вдома).

4. Для дітей з патологією ОРА - індивідуальне лікування і реабілітація в умовах лікувально-профілактичних установ або профілактично-коригувальні заходи в умовах навчального закладу за рекомендаціями лікаря-ортопеда.

\section{Пропозиції}

Серед дітей за два роки темп зниження поширеності порушень постави відрізнявся на різних рівнях (школи - 75,0 \%, району - 14,4 \%; міста - 10,1 \%) і плоскостопості: (школи - 45, \%, району - 21,9 \%, міста - 10,4 \%. Тому існує необхідність у такому:

- покращенні міжвідомчої інтеграції, розвиток партнерських відносин між секторами охорони здоров'я та освіти на державному та регіональному рівнях;

- удосконаленні механізмів ортопедичної допомоги дітям, збільшення кратності оглядів дітей лікарем-ортопедом не менше, ніж один раз на півріччя;

- розвитку волонтерського руху з розповсюдження інформаційних матеріалів щодо проблеми здоров'я опорно-рухового апарату, проведення тренінгів;

- залучення медичного персоналу центрів здоров'я та установ спортивної медицини до медичних оглядів з визначення стану опорно-рухового апарату дітей та проведення занять з лікувальної фрізкультури.

\section{References}

1. Antomonov M. Yu. Mathematical Processing and Analysis of Medical and Biological Data / M. Yu.Antomonov. Kiev: Ukrainian Military-Medical Academy, 2006. - 558 p.

2. Introduction of the Child's Beautiful Posture Programme for Prophylaxis and Correction of Disorders of Locomotor System in the Educational Process at the Institutions of Pre-School and Secondary Education: Method.Rec. (№168.11/38.12) / N. S. Polka, S. V.Gozak, O. T.Yelizarova et al. - Kiev, 2012. - 36 p.

3. Kucherenko V. Application of the Statistical Analysis Methods for studing of Public Health / V. Kucherenko, O. Manerova, G. Kraieva. - Moscow, GEOTAR-Media, 2007. 192 p.

4. Kuchma V. R. School of Health: Organization of the Work, Monitoring of Development and Efficiency (Audit of the School in the Sphere of Children's Health Preserving) / [V. R. Kuchma, L. M. Sukhareva, I. K.Rapoport et al.]. - Moscow: Prosveshchenie, 2011.- 142 p.

5. Last D. Epidemiological Dictionary: Ed. John M. Last. Moscow: Globus, 2009. - 316 p.

6. Polka N. S. Improvement of Medical and Prophylactic Support of the Children at Secondary Educational Institutions - Requirements of the Time / N. S. Polka, S. V. Gozak, T. V. Stankevich // Environment and Health. - 2009. - N 1. - P. 52-54.

Надійшла 20.11.2013 